\title{
The Effects of Different Carbon Sources and Changes in the Growth Medium on the Shape of Cells of the Yeast Trigonopsis variabilis
}

\author{
By D. K. MATTHEWSON AND J. A. BARNETT* \\ School of Biological Sciences, University of East Anglia, Norwich
}

(Received 25 April 1974; revised 6 May 1974)

\section{INTRODUCTION}

The salient features of Trigonopsis variabilis are (i) its three-cornered cells and (ii) the dimorphism between those and oval cells (Slooff, 1970). Working with the type-strain, CBS I040, Sentheshanmuganathan \& Nickerson (1962) found that D,L-methionine or choline, as sole source of nitrogen, favoured the formation of three-cornered cells, and attributed this to the properties of methionine as a methyl group donor. With no methyl donor, oval cells were formed. Subsequently, Šašek \& Becker (1969) showed that other amino acids, such as proline, hydroxyproline or alanine, have much the same effect as methionine in increasing the proportion of three-cornered cells.

Another strain of Trigonopsis variabilis, CBS 4095, has been examined by Verona \& Zardetto de Toledo (1958), Rambelli (1959) and Picci \& Verona (1962). These authors reported that the proportions of the two shapes of cell were affected by temperature as well as by nitrogen source. Strain CBS 4095 appears to form a wider range of cell shapes than CBS 1040 (Rambelli, 1959).

The present paper describes the effects of varying the source of carbon and the influence of expended medium on the shapes of exponentially growing cells of CBS IO40.

\section{METHODS}

The yeast was maintained on Difco Bacto-YM agar ( $\mathrm{pH} \mathrm{6.2).} \mathrm{The} \mathrm{experimental}$ medium, modified from that of Šašek \& Becker (1969), contained (final quantities/l): $\mathrm{KH}_{2} \mathrm{PO}_{4}, 2 \mathrm{~g} ; \mathrm{MgSO}_{4} \cdot 7 \mathrm{H}_{2} \mathrm{O}, \mathrm{I} \cdot 2 \mathrm{~g} ; \mathrm{CaCl}_{2} .6 \mathrm{H}_{2} \mathrm{O}, \mathrm{I} \cdot 2 \mathrm{~g} ; \mathrm{H}_{3} \mathrm{BO}_{3}, 50 \mathrm{mg} ; \mathrm{Na}_{2} \mathrm{MoO}_{4} \cdot 2 \mathrm{H}_{2} \mathrm{O}$, $4 \mathrm{mg} ; \mathrm{MnSO}_{4} \cdot 4 \mathrm{H}_{2} \mathrm{O}, 20 \mathrm{mg}$; $\mathrm{ZnSO}_{4} \cdot 7 \mathrm{H}_{2} \mathrm{O}, 20 \mathrm{mg}$; $\mathrm{FeSO}_{4} \cdot 7 \mathrm{H}_{2} \mathrm{O}$, I $2 \mathrm{mg} ; \mathrm{CuSO}_{4} \cdot{ }_{5} \mathrm{H}_{2} \mathrm{O}$, $56 \mathrm{mg}$. The reagents were all of analytical grade. The medium was sterilized at $120{ }^{\circ} \mathrm{C}$ for I $5 \mathrm{~min}$; filter-sterilized biotin ( $16 \mu \mathrm{g} / \mathrm{l})$ and thiamin ( $1.6 \mathrm{mg} / \mathrm{l}$ ) were added. The following were added to the medium as indicated. Nitrogen sources ( $20 \mathrm{~mm}$ final concentration):D,Lmethionine, L-proline, $\left(\mathrm{NH}_{4}\right)_{2} \mathrm{SO}_{4}$; carbon sources ( $100 \mathrm{~mm}$ final concentration): D-glucose, D-fructose (BDH, glucose-free), D-galactose, L-sorbose, glycerol, succinic acid (the last adjusted to $\mathrm{pH} 4$ with sodium hydroxide.) The sugars were filter-sterilized; other compounds were autoclaved at $120^{\circ} \mathrm{C}$ for $15 \mathrm{~min}$. No growth occurred within $\mathrm{I} 20 \mathrm{~h}$ from inoculation with lactate as carbon source, although Slooff (1970) has reported that it is utilized.

All incubations were at $26{ }^{\circ} \mathrm{C}$ in the dark in $500 \mathrm{ml}$ conical flasks containing $200 \mathrm{ml}$ medium. Each flask was inoculated with about I mg dry wt of yeast from a I-day-old YM agar slope, and was incubated in a Gallenkamp Orbital shaker at $175 \mathrm{rev} . / \mathrm{min}$. Growth was measured with a nephelometer, calibrated in terms of dry weight (Barnett, 1968) for both three-cornered and oval cells, which gave closely similar results. $\mathrm{pH}$ was measured 

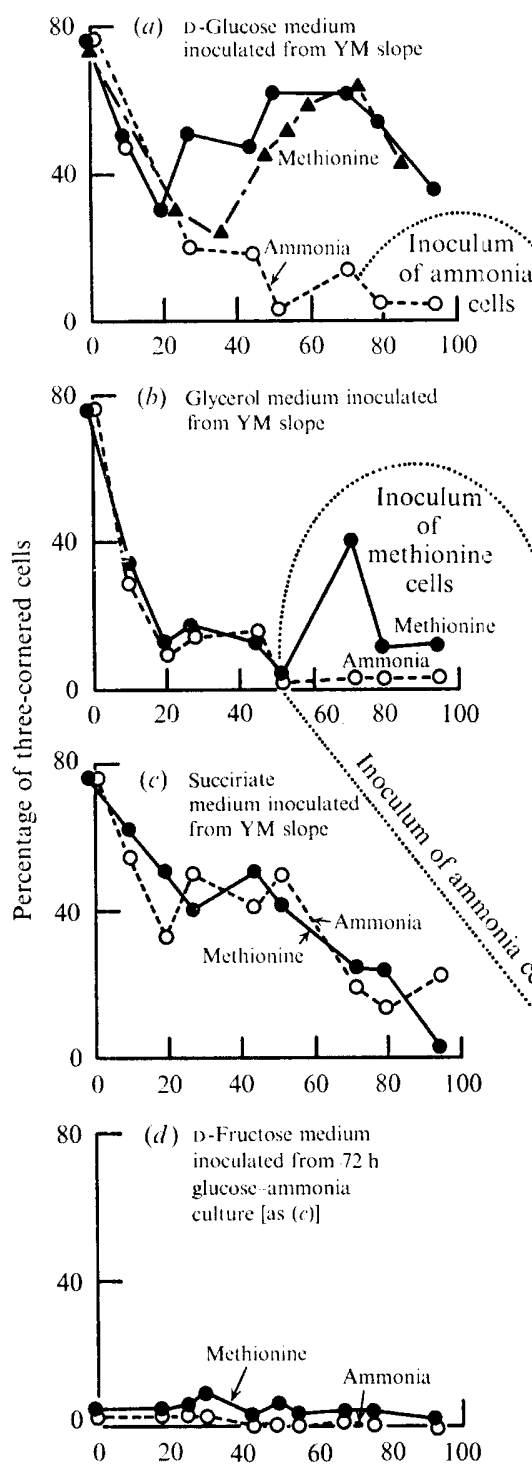

(e) D-Glucose medium inoculated from $72 \mathrm{~h}$ glucose ammonia culture

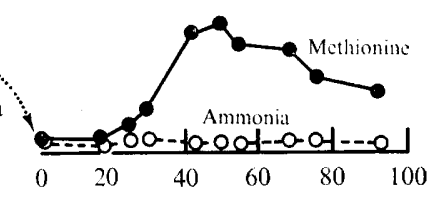

(f) Glycerol + methionine medium inoculated from $50 \mathrm{~h}$ glycerol-methionine culture

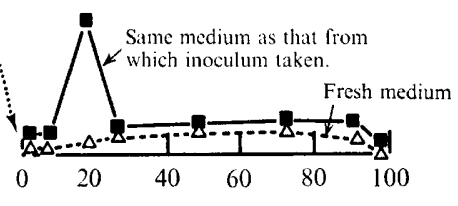

(g) Glycerol + methionine medium inoculated from $50 \mathrm{~h}$ glycerol-ammonia culture
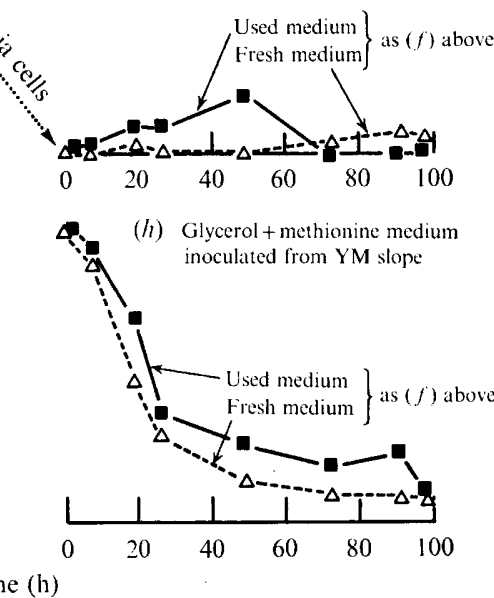

Fig. I. The proportion of three-cornered cells in growing cultures of Trigonopsis variabilis: effects of (i) various carbon-sources, combined with either D, L-methionine or $\left(\mathrm{NH}_{4}\right)_{2} \mathrm{SO}_{4}$ as nitrogensource, (ii) of differences in the medium for growing the inocula, and (iii) of using medium in which the yeast had already been growing. In $(a)$ two plots $(\boldsymbol{A}$ and $\boldsymbol{\Delta})$ are given for methionine cells to exemplify the agreement between duplicate experiments.

about every to h during growth. Each experiment was done at least twice. In certain cases, cultures were centrifuged and washed aseptically, the supernatant filter-sterilized and reinoculated.

Live yeast was examined microscopically by phase-contrast and Nomarski optics. Nigrosin staining of the yeast (Sentheshanmuganathan \& Nickerson, I962; Šašek \& Becker, I969) 
was tried but abandoned as it appeared to distort the cells. The shapes of at least 300 cells were recorded for each sample. With Schachner (1929), we observed between 10 and $20 \%$ of forms to be intermediate between three-cornered and oval cells and scored them arbitrarily into the one group or the other.

Irrespective of the source of carbon, the specific growth rate was between 0.1 and 0.2 generations/ $\mathrm{h}$ for $\left(\mathrm{NH}_{4}\right)_{2} \mathrm{SO}_{4}$ and tetween 0.075 and $\mathrm{O} . \mathrm{I}$ generations/h for $\mathrm{D}, \mathrm{L}$-methionine. Measured with a Model A Coulter Counter (Coulter Electronic Corp., U.S.A.), yeasts from glycerol medium in mid-exponential growth, containing $3 \%$ three-cornered cells, had an approximate mean cell volume of $42 \mu \mathrm{m}^{3}$, and those from a I-day-old YM slope $(83 \%$ threecornered) had one of $54 \mu \mathrm{m}^{3} ; 250000$ cells were examined in each case.

\section{RESULTS AND DISCUSSION}

Varying the source of carbon, as well as that of nitrogen, affects the proportion of threecornered cells during growth (Fig. I). We have confirmed the observations of Šašek \& Becker (1969) on (i) changes in $\mathrm{pH}$ of the media during growth, (ii) cell-yields, and (iii) proportions of three-cornered cells, using L-proline, $\left(\mathrm{NH}_{4}\right)_{2} \mathrm{SO}_{4}$ or D,L-methionine, with D-glucose as the source of carbon. However, with our method of scoring for cell-shape, the maxima we found were always lower (about $70 \%$ instead of $90 \%$, e.g. Fig. I $a$ ), than those obtained by Šašek and Becker. The much higher proportion of three-cornered cells on methionine as nitrogen-source than on ammonia, as found in glucose medium (Sentheshanmuganathan \& Nickerson, 1962; Šašek \& Becker, 1969; Fig. I $a$ ), occurred also with glycerol (Fig. I b), D-galactose and L-sorbose, but not with succinate (Fig. I $c$ ) or D-fructose (Fig. I $d$ ). The pronounced peak with the glycerol-methionine medium (Fig. I $b$ ) occurred at between 60 and $70 \mathrm{~h}$ in each of four experiments. For D-glucose, D-galactose and L-sorbose, the maxima occurred at between 50 and $70 \mathrm{~h}$, that is at about mid-exponential growth.

The high proportion of three-cornered cells from YM slopes was comparable with those found for similar media by Schachner (1929) and Slooff (1970). In order to test how far this affected the experiments, inoculations were also made from exponentially growing cultures with few three-cornered cells, i.e. $72 \mathrm{~h}$ after inoculation in the glucose-ammonia medium. It can be seen that the difference in proportion of the two kinds of cell between growths on methionine and ammonia are still greatest at about $50 \mathrm{~h}$ (compare Fig. I $a, e$ ). Whether the inocula were from YM slopes or liquid cultures did not affect the growth rates.

In order to examine effects of changes in the media during growth, yeast was centrifuged aseptically from glycerol-methionine medium at $50 \mathrm{~h}$ (Fig. I $b$ ), i.e. just before the occurrence of maximum three-cornered cells. This yeast was inoculated equally (i) into fresh glycerolmethionine medium and (ii) back into the medium whence it came. Figure $\mathrm{I}(f)$ shows that yeast returned to its own medium increased its proportion of three-cornered cells as though it had not been removed, whereas in fresh medium the cells almost all remained oval. However, the result of inoculating glycerol-ammonia cells (Fig. I $b$ ) into fresh and used glycerol-methionine medium (Fig. I $g$ ) showed clearly that the proportion of three-cornered cells is affected both by how the inoculum is grown and by the changes in the medium during growth. These changes are likely to be either the production of one or more catabolites or the exhaustion of one or more substrates, rather than an alteration of $\mathrm{pH}$ which varied similarly throughout growth in each medium.

To sum up, we have shown that the tendency of Trigonopsis variabilis CBS I040 to form three-cornered cells is affected not only by the kind of nitrogen source used for growth, but also by the carbon source and by changes in the growth medium produced by the yeast itself. 
This last influence, seen dramatically in the results of experiments with glycerol-methionine medium, confirmed the conclusion of Bartnicki-Garcia \& McMurrough (197I) that endogenous conditions which favour the formation of three-cornered cells are highly transient.

We thank Dr A. P. Sims for his valuable suggestions and criticisms.

\section{REFERENCES}

BARNETT, J. A. (1968). The catabolism of acyclic polyols by yeasts. Journal of General Microbiology 52, 131159.

Bartnicki-Garcia, S. \& MCMURrough, I. (197I). Biochemistry of morphogenesis in yeasts. In The Yeasts, vol. 2, pp. 44I-49I. Edited by A. H. Rose and J. S. Harrison. London: Academic Press.

Picci, G. \& VERona, O. (1962). Su di alcuni fattori che influenzano la morfogenesi di Trigonopsis variabilis Sch. Atti Istituto Botanico della Università Laboratorio Crittogamico Pavia, Serie V, 2o, 3-8.

Rambell, A. (1959). Intorno a qualche aspetto nutrizionale e morfologico di Trigonopsis variabilis Schachner. Nuovo Giornale Botanico Italiano 66, 296-300.

S̆AŠEK, V. \& BECKER, G. E. (1969). Effect of different nitrogen sources on the cellular form of Trigonopsis variabilis. Journal of Bacteriology 99, 89I-892.

SCHACHNER, J. (1929). Trigonopsis variabilis nov. gen. et spec. Zeitschrift fïr das gesamte Brauwesen 52, $137-142$.

Sentheshanmuganathan, S. \& Nickerson, W. J. (I962). Nutritional control of cellular form in Trigonopsis variabilis. Journal of General Microbiology 27, 437-449.

SLoof, W. C. (1970). Trigonopsis Schachner. In The Yeasts: A Taxonomic Study, pp. 1353-1 357. Edited by J. Lodder. Amsterdam: North-Holland Publishing.

Verona, O. \& Zardetto de Toledo, O. (1958). Reisolamento di una rara specie di lievito: Trigonopsis variabilis Schachner. Archiv für Mikrobiologie 32, 25-28. 